Money and the Modern Mind 



\section{Money and the}

Modern Mind

Georg Simmel's

Philosophy of Money

Gianfranco Poggi 
University of California Press

Berkeley and Los Angeles, California

University of California Press, Ltd.

London, England

(C) 1993 by

The Regents of the University of California

\section{Library of Congress Cataloging-in-Publication Data}

Poggi, Gianfranco.

Money and the modern mind : Georg Simmel's Philosophy of money / Gianfranco Poggi.

p. $\mathrm{cm}$.

Includes bibliographical references and index.

ISBN 0-520-07571-4

1. Simmel, Georg, 1858-1918. Philosophie des Geldes. 2. Money.

I. Title.

HG221.S56P477 1993

$332.4-$ dc. 20

CIP

Printed in the United States of America

123456789

The paper used in this publication meets the minimum requirements of American National Standard for Information Sciences-Permanence of Paper for Printed Library Materials, ANSI Z39.48-1984. $\infty$ 
To my fellow Fellows at the Center for Advanced Study in the Behavioral Sciences 1989-1990 
